\title{
Secondary metabolites in leaves of hybrid aspen are affected by the competitive status and early thinning in dense coppices
}

\author{
Linda Rusalepp ${ }^{1,2}\left(\mathbb{D} \cdot\right.$ Reimo Lutter $^{3,4}\left(\mathbb{1} \cdot\right.$ Heiki Hepner $^{3} \cdot$ Ants Kaasik $^{1} \oplus \cdot$ Arvo Tullus $^{1} \oplus$
}

Received: 17 January 2020 / Accepted: 26 October 2020 / Published online: 5 January 2021

(c) INRAE and Springer-Verlag France SAS, part of Springer Nature 2021

\begin{abstract}
- Key message Non-selective thinning of a hybrid aspen coppice stands via corridor or cross-corridor cutting impacts residual trees differently depending on their competitive status. Suppressed residual trees' metabolic profile indicates increased stress level, especially after cross-corridor thinning.

- Context Early thinning with regular corridor harvests is proposed for the management of post-harvest re-sprouted hybrid aspen (Populus tremula L. $\times$ P. tremuloides Michx.) coppice stands. The selection of remaining trees is not size-based and their physiological acclimation to the post-thinning conditions is unknown.

- Aims To analyse differences in secondary metabolite profile between thinning treatments and trees competitive status.

- Methods We used an HPLC-qTOF mass spectrometer to analyse the leaf extracts of dominant and suppressed trees from stands with different thinning intensities: un-thinned control with basal area of $15.4 \pm 1.52 \mathrm{~m}^{2} \mathrm{ha}^{-1}$, corridor thinning with basal area of $8.5 \pm 0.46 \mathrm{~m}^{2} \mathrm{ha}^{-1}$ and cross-corridor thinning with basal area of $3.9 \pm 0.34 \mathrm{~m}^{2} \mathrm{ha}^{-1}$.

- Results Competitive status and thinning treatment both had significant effects on the contents of compounds. Higher exposure to irradiance increased the contents of flavonoids and hydroxycinnamates. Corridor thinning treatments doubled the foliar contents of secondary metabolites and lowered macronutrient contents in competitively suppressed residual trees. Dominant residual trees were not affected in this respect.

- Conclusion Forest management practice and competitive status can significantly modify the metabolite profile in tree leaves. After corridor thinning of a young aspen coppice stand, the small-sized residual trees may initially respond with increased allocation to leaf chemical defence rather than to productivity.
\end{abstract}

Keywords Growth-defense trade-off · Intraspecific competition $\cdot$ Populus $\cdot$ Forest management $\cdot$ HPLC

\section{Introduction}

Several theoretical frameworks have been proposed to explain the trade-off between the allocation of photosynthates to growth and defence, which is reflected also by the contents of secondary metabolites (Stamp 2003; Matyssek et al. 2005; Neilson et al. 2013). In an environment rich in

Handling Editor: Jean-Michel Leban

Contribution of the co-authors L.R., R.L. and A.T. conceived and designed the research. R.L., H.H. and A.T. conducted the fieldwork. L.R. conducted sample preparation and HPLC analysis. A.K and A.T. contributed to data analysis. L.R., A.T. and R.L. wrote the paper.

Linda Rusalepp

linda.rusalepp@ut.ee

Extended author information available on the last page of the article resources (e.g., light), the accumulated carbon would primarily be allocated to plant growth. In circumstances where some environmental factors (moderate drought or poor supply of nutrients, low temperature) limit plant growth more than photosynthesis, the assimilated carbon investment to the production of secondary metabolites increases (Herms and Mattson 1992). In addition to abiotic factors, the resource supply of individual plants is also determined by biotic factors, including competition with neighbouring plants, which can therefore play a crucial role in growth-defence trade-off (Matyssek et al. 2005). However, the physiological mechanisms underlying tree responses to competition are still poorly known (Pommerening and Sánchez Meador 2018).

Thinning is one of the major silvicultural practices that allow to reduce competition and to reallocate resources and growing space among the remaining trees (Long et al. 2004; Forrester 2019); early-stage thinning is especially 
recommended for fast-growing northern hardwood species (Rytter 2013).

One of the fastest-growing trees in Northern Europe is hybrid aspen (Populus tremula L. $\times$ P. tremuloides Michx.) (Tullus et al. 2012). Short-rotation hybrid aspen stands are established as plantations of pre-selected fast-growing clones. One possible management regime proposed for second-generation hybrid aspen stands (which re-generate vegetatively from root and stump sprouts) includes the combined production of assortments, where energy wood is obtained from early corridor harvests (at the age of 2-4 years), and the remaining trees are grown for a longer rotation period for the production of pulpwood and logs (Rytter 2006; Mc Carthy and Rytter 2015). The plantations are usually sparse, with about 1000 stems ha $^{-1}$ (Tullus et al. 2012), but the post-harvest regenerating coppice stands can be dense with over 100,000 stems ha ${ }^{-1}$ (Rytter 2006; Hytönen 2018). However, we do not know how the physiology of hybrid aspen responds to intensive crowding and how much the growth-defence trade-off varies with the tree competitive status. Moreover, growth-defence trade-off has rarely been considered when evaluating the sustainability of different forest management practices. However, it is increasingly acknowledged to improve pathogen resistance in tree breeding (Desprez-Loustau et al. 2016).

Many classes of secondary compounds have been determined in various Populus spp. (Chen et al. 2009), including salicylates, tannins, phenolic acids and flavonol glucosides, but also the omnipresent jasmonic acid and its derivatives. Jasmonates (JA) and salicylates (SA) are both considered plant stress hormones. Although SA are toxic for insects (Hemming and Lindroth 1995; Chen et al. 2009 and citations therein), the SA pathway is more associated with the defence against pathogens, while JA are thought to regulate more the antiherbivore defence mechanism (Smith et al. 2009). Both abiotic and biotic stresses can influence the levels of JA and SA, including wounding, ozone, UV radiation and temperature (León et al. 2001; Glauser et al. 2008; Häikiö et al. 2008; Khan and Khan 2013; Jacobo-Velázquez et al. 2015; Julkunen-Tiitto et al. 2015; Nissinen et al. 2017). Flavonoids mainly act as antioxidants, and their synthesis is largely induced by UV irradiation (Lavola 1998; Kotilainen et al. 2008; Morales et al. 2010; Julkunen-Tiitto et al. 2015; Nissinen et al. 2017).

The aim of this study was to determine the secondary metabolite profile of leaves of young vegetatively regenerated hybrid aspen trees and to analyse the effect of early thinning on the secondary metabolite profile of competitively dominant and suppressed residual trees. We hypothesised that (i) concentrations of secondary metabolites are higher in competitively suppressed trees than in dominant trees and (ii) thinning of the hybrid aspen coppice stand decreases secondary metabolism in the remaining trees and diminishes the difference between dominant and suppressed tree secondary metabolite profiles.

\section{Material and methods}

\subsection{Study site and experimental design}

This study was carried out in a hybrid aspen (Populus tremula L. $\times$ P. tremuloides Michx.) regeneration experimental site in southern Estonia (58 $19^{\prime} 40^{\prime \prime} \mathrm{N}, 26^{\circ} 33^{\prime} 16^{\prime \prime}$ E, $71 \mathrm{~m}$ a.s.1.). The mean annual temperature of the sampling year (2017) was $6.3^{\circ} \mathrm{C}$, with a mean annual precipitation of $726 \mathrm{~mm}$, which are, respectively, $9 \%$ lower and $6 \%$ higher compared to the mean of the previous 5 years (Estonian Weather Service 2018).

The experimental site was established in spring 2014 in a vegetatively regenerated hybrid aspen stand, which had emerged from root and stump sprouts after clearcutting of a 14-year-old hybrid aspen plantation. The clear-felled stand had been established as a commercial plantation, where hybrid aspens belonging to 14 different clones were planted $\left(1300\right.$ trees $\left.\mathrm{ha}^{-1}\right)$ in a random mixture; therefore, the position of clones in an individual tree level is unknown; these clones originate from the same breeding program in Finland and the plant material improvement level and origin are similar (Tullus et al. 2007). The experimental area covers about 2 ha and was fenced against browsing by game. Prior to plantation establishment, the site was a cropland. The soil type that prevails homogeneously across the area is Retic Umbrisol (IUSS Working Group WRB 2015), which is a typical agricultural soil in this region.

The initial density of the hybrid aspen coppice stand was 94,000 trees $\mathrm{ha}^{-1}$, and this did not vary significantly across the 2-ha study area (Hepner et al. 2020). The thinning trial of the hybrid aspen coppice stand started after the second growing season (early spring 2016). Areas with two different thinning intensities were created, keeping some areas as unmanaged control (Fig. 1). Thinning was done systematically using (i) the corridor method $(\mathrm{C})$, where 2-m-wide corridors were cut, leaving 1-m-wide un-cut strips of trees, and where the initial density was reduced by about $2 / 3$ to 23,000 trees $^{-1}$ and (ii) the crosscorridor method (CC), where the 2-m-wide corridors were cut in two perpendicular directions, leaving $1 \times 1$-m uncut patches of trees, and where the initial density was reduced by about $8 / 9$ to 9000 trees $\mathrm{ha}^{-1}$. All treatments were randomly distributed across the experimental area in three $30 \times 40$-m sized replications. Each replication contained three circle plots with a size of $12.6 \mathrm{~m}^{2}$ (radius $=2 \mathrm{~m}$ ) in the control and $28.3 \mathrm{~m}^{2}$ (radius $=3 \mathrm{~m}$ ) in the corridor and cross-corridor treatments. 
Fig. 1 a Design of the experimental area, where treatment replications are indicated with capital letters (A, F, H-unmanaged control; B, D, I-corridor thinning; C, E, G-crosscorridor thinning). Numbers 1 , 2 and 3 indicate the circle plots in each replication. $\mathbf{b}$ Graphical illustration of the applied thinning treatments a)

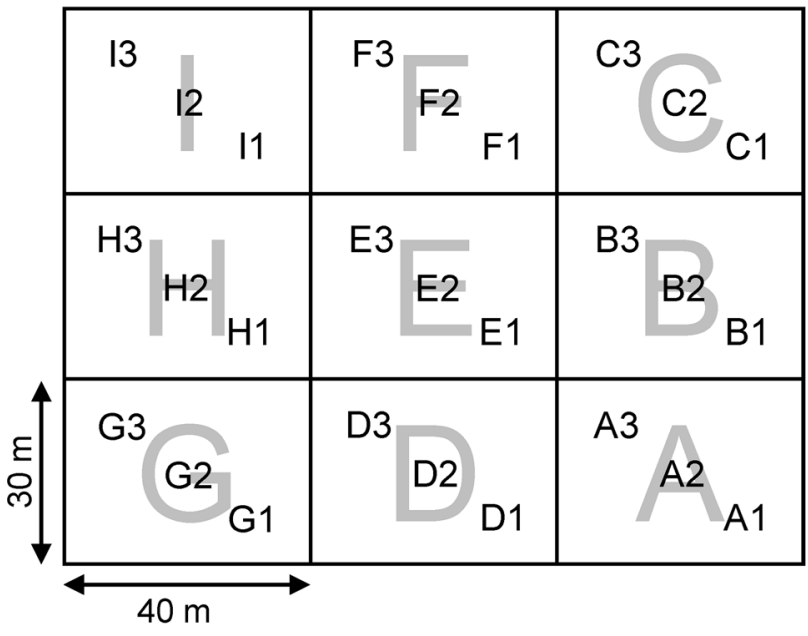

b)

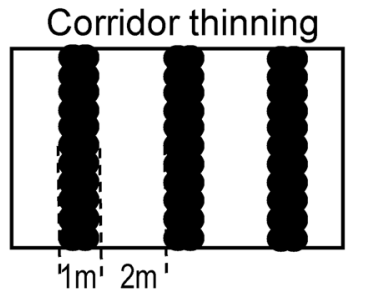

Cross-corridor thinning

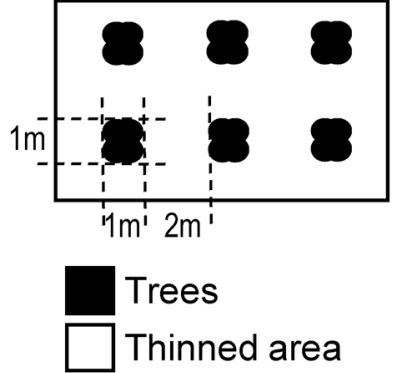

\subsection{Tree and leaf sampling}

Leaf sampling was performed in mid-July 2017. Two model trees with different competitive statuses (a dominant and a suppressed tree) were chosen next to each circle plot. The model trees were selected so that the stem diameter of the dominant tree was greater than the upper diameter quartile in the given sample plot, and the diameter of the suppressed tree was less than the lower diameter quartile. Model trees were harvested, and the basic growth characteristics were measured in the field (Table 1). All leaves were separated from the model trees, and fresh weight was determined. Twenty sample leaves were randomly selected across the crown from each model tree, weighed, and dried to constant weight at $65^{\circ} \mathrm{C}$. Subsequently, the leaves were weighed to the nearest $0.01 \mathrm{~g}$, and single leaf blade area was measured with the software package WinFolia (Regent Instruments Canada INC.) to estimate the mean leaf weight per area $\left(\mathrm{LWA}, \mathrm{g} \mathrm{m}^{-2}\right)$.

\subsection{Foliar nutrients}

The sampled leaves were ground prior to the chemical analysis. Leaf total nitrogen content $([\mathrm{N}], \%)$ was analysed with the Kjeldahl method, using a Kjeltec Auto 1030 Analyzer (Foss Tecator AB, Höganäs, Sweden). Phosphorus ([P], \%) was determined spectrophotometrically via Kjeldahl digestion, using a FIAstar 5000 Analyzer (FOSS Tecator AB), and potassium $([\mathrm{K}], \%)$ was determined flame-photometrically using the Sherwood Model 425 Flame Photometer in the Laboratory of Plant Biochemistry at the Estonian University of Life Sciences.

\subsection{LC-MS analysis}

The extracts were chromatographically analysed using a 1290 Infinity system (Agilent Technologies, Waldbronn, Germany), coupled to an Agilent 6450 Q-TOF mass spectrometer equipped with a Jetstream ESI source.

Table 1 Growth characteristics

\begin{tabular}{llllllll}
\hline $\mathrm{T}$ & $\mathrm{CS}$ & $\mathrm{H}(\mathrm{cm})$ & $\mathrm{DBH}(\mathrm{mm})$ & LWA $\left(\mathrm{g} \mathrm{m}^{-2}\right)$ & {$[\mathrm{N}](\%)$} & {$[\mathrm{P}](\%)$} & {$[\mathrm{K}](\%)$} \\
\hline $\mathrm{UT}$ & $\mathrm{D}$ & $569 \pm 12 \mathrm{a}$ & $34 \pm 1.2 \mathrm{a}$ & $73 \pm 1.1 \mathrm{c}$ & $2.8 \pm 0.06 \mathrm{ab}$ & $0.31 \pm 0.014 \mathrm{ab}$ & $0.68 \pm 0.07 \mathrm{~b}$ \\
$\mathrm{C}$ & $\mathrm{D}$ & $553 \pm 20 \mathrm{a}$ & $39 \pm 2.5 \mathrm{a}$ & $84 \pm 2.6 \mathrm{ab}$ & $2.5 \pm 0.05 \mathrm{~cd}$ & $0.28 \pm 0.009 \mathrm{ab}$ & $0.66 \pm 0.053 \mathrm{~b}$ \\
$\mathrm{CC}$ & $\mathrm{D}$ & $521 \pm 18 \mathrm{a} 38 \pm 1.1 \mathrm{a}$ & $90 \pm 1.5 \mathrm{a}$ & $2.5 \pm 0.04 \mathrm{bc}$ & $0.26 \pm 0.008 \mathrm{~b}$ & $0.59 \pm 0.015 \mathrm{~b}$ \\
$\mathrm{UT}$ & $\mathrm{S}$ & $315 \pm 25 \mathrm{~b} 12 \pm 1.4 \mathrm{~b}$ & $47 \pm 2.1 \mathrm{~d}$ & $3.0 \pm 0.09 \mathrm{a}$ & $0.34 \pm 0.019 \mathrm{a}$ & $0.94 \pm 0.039 \mathrm{a}$ \\
$\mathrm{C}$ & $\mathrm{S}$ & $304 \pm 14 \mathrm{~b} 14 \pm 0.9 \mathrm{~b}$ & $66 \pm 2.0 \mathrm{c}$ & $2.5 \pm 0.06 \mathrm{~cd}$ & $0.28 \pm 0.011 \mathrm{ab}$ & $0.69 \pm 0.030 \mathrm{~b}$ \\
$\mathrm{CC}$ & $\mathrm{S}$ & $255 \pm 17 \mathrm{~b} 11 \pm 1.3 \mathrm{~b}$ & $75 \pm 1.5 \mathrm{bc}$ & $2.2 \pm 0.07 \mathrm{~d}$ & $0.25 \pm 0.015 \mathrm{~b}$ & $0.63 \pm 0.017 \mathrm{~b}$ \\
\hline
\end{tabular}

( $H$ height, $D B H$, stem diameter at breast height), foliar macronutrients and leaf weight per area (LWA) of the analysed model trees $(n=54)$, arithmetic group means \pm SE, followed by letters indicating the results of Tukey's test. $T$ thinning treatment (UT un-thinned, $C$ corridor thinning, $C C$ cross-corridor thinning); $C S$, tree competitive status ( $D$ dominant, $S$ suppressed) 

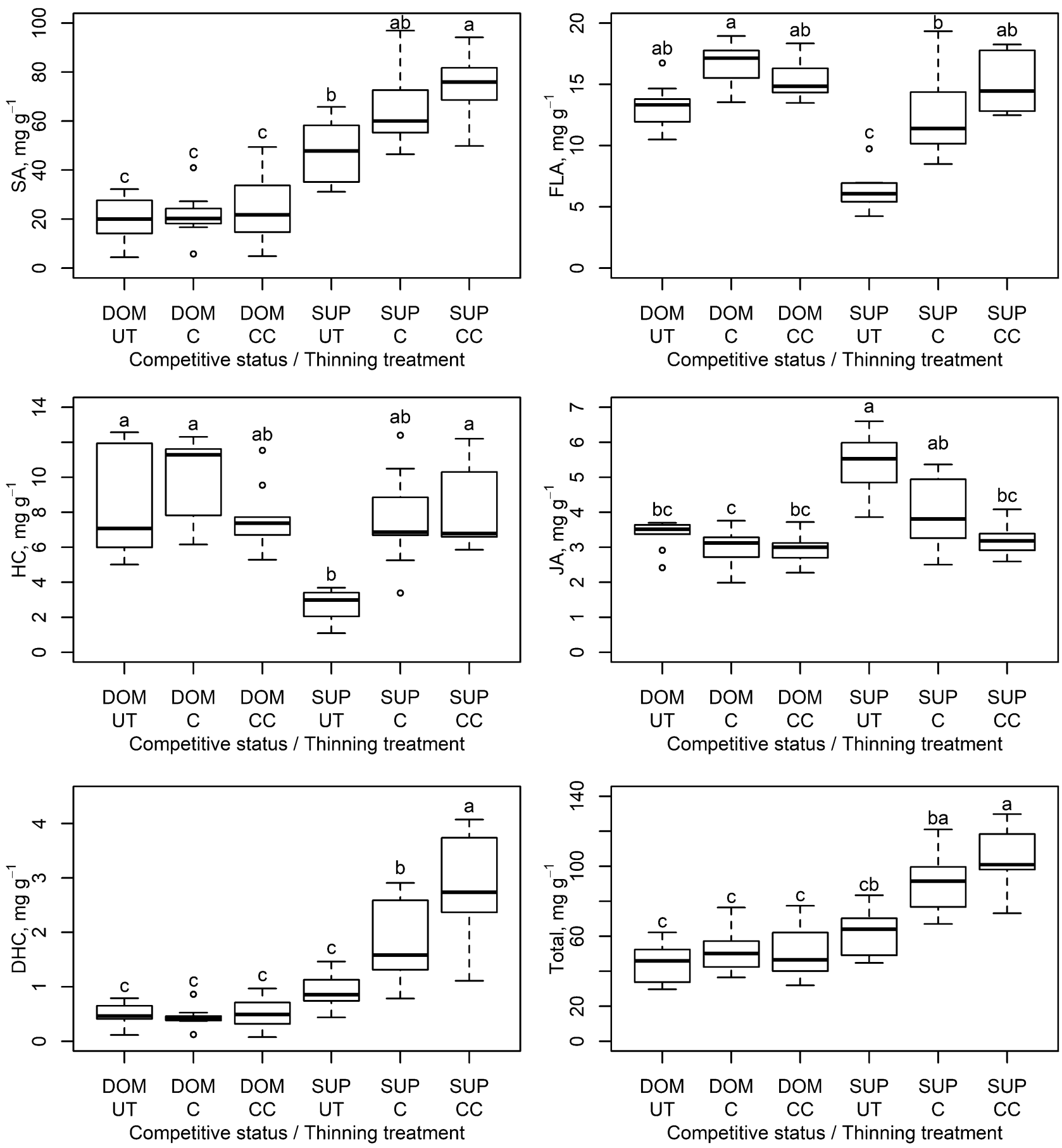

Fig. 2 Boxplots of the contents of foliar secondary metabolite classes (SA, salicylates; FLA, flavonoids; HC, hydroxycinnamates; JA, jasmonates; DHC, dihydrochalcones) by tree competitive status (DOM, dominant; SUP, suppressed) and thinning treatment (UT, un-thinned; $\mathrm{C}$, corridor thinning; CC, cross-corridor thinning). Significantly dif-

We tested 100, 80 and $50 \%(\mathrm{v} / \mathrm{v})$ methanol solutions in water for extracting ground leaves, of which the $80 \%$ methanol solution gave the highest chromatographic peaks and was therefore chosen as extraction solvent. The ground

ferent groups are distinguished with different letters, based on Tukey's test. Boxes indicate lower and upper quartile, the horizontal line marks the median and the whiskers extend to the most extreme data point, which is no more than 1.5 times the interquartile range from the box. Outliers are shown with circles

plant material was extracted $(1: 20 \mathrm{w} / \mathrm{v})$ for $24 \mathrm{~h}$ in darkness at room temperature, with occasional shaking. Subsequently, the extracts were centrifuged at $12,000 \mathrm{~g}$ for $10 \mathrm{~min}$ with an Eppendorf MiniSpin (Eppendorf AG, Hamburg, 
Germany). The obtained supernatants were subjected to a Zorbax 300SB-C18 column $(2.1 \times 150 \mathrm{~mm}$; $5 \mu \mathrm{m}$; Agilent Technologies) kept at $40^{\circ} \mathrm{C}$. For the elution of the samples, a gradient of $0.1 \%$ formic acid in water (A) and acetonitrile (B) was used as follows: $0-2.0 \mathrm{~min} 1 \% \mathrm{~B}, 69.0 \mathrm{~min}$ $27 \%$ B, 72.0-79.0 min 95\% B, $79.1 \mathrm{~min} 1 \% \mathrm{~B}$, regeneration time $9 \mathrm{~min}$. The eluent flow rate was set to $0.3 \mathrm{~mL} / \mathrm{min}$, and the injection volume was $3 \mu \mathrm{L}$. The mass spectrometer was working in negative ionisation mode in the mass-to-charge ratio $(\mathrm{m} / \mathrm{z})$ range of $100-1000 \mathrm{amu}$. Data acquisition and initial data processing were carried out using the MassHunter software (Agilent Technologies).

Compounds were identified by comparison of the $\mathrm{m} / \mathrm{z}$ value, retention time, UV spectra and $\mathrm{MS}^{2}$ fragmentation patterns with standards or by comparing data from the literature or the METLIN database (Agilent Technologies). External calibration curves of standards were used for the quantitation of compounds listed in Table 3, using MSextracted ion chromatogram (EIC) peak areas. The generated dataset can be accessed at the following link: https://doi. org/10.5281/zenodo.4095450 (Rusalepp et al. 2020).

\subsection{Chemicals}

Formic acid, acetonitrile, methanol, salicin, jasmonic acid, catechin, chlorogenic acid, procyanidin B1, kaempferol-3-Oglucoside, rutin, myricetin and phloridzin were acquired from Sigma-Aldrich (Merck KGaA, Darmstadt, Germany).

\subsection{Statistical analyses}

The main effects of tree competitive status (dominant or suppressed) and thinning intensity (un-thinned control, corridor thinning, cross-corridor thinning) and their interactive effect on the foliar secondary metabolites were analysed with a linear mixed effects model (LMM), where replication and sample plot were treated as random factors. The LMM analysis was performed with the function lmer in the package lme4 of the R Statistics software (R Core Team 2018). The significance of the models was evaluated by comparing each full model with an intercept-only model, using the chisquare test. As several chemical constituents were analysed in each sample, Bonferroni correction for multiple testing was applied to the $p$ value obtained from the chi-square test. When significant factor effects were detected, the group means were compared with Tukey's test.

Linear correlations between secondary metabolites, foliar nutrients, LWA and stand basal area $\left(G, \mathrm{~m}^{2} \mathrm{ha}^{-1}\right)$ were analysed separately for dominant and suppressed trees, based on pooled data from all treatments and plots.

Normality of model residuals was checked from residual histograms and Q-Q plots. Most of the secondary metabolite concentrations were log-transformed prior to statistical tests. A significance level of $\alpha=0.05$ was used to reject the null hypothesis after statistical tests.

\section{Results}

Salicin derivatives (SA) were the most abundant class of compounds in the analysed samples $(4.42-96.95 \mathrm{mg} / \mathrm{g}$ leaf dry weight), followed by flavonoids (FLA) $(4.24-22.36 \mathrm{mg} / \mathrm{g}$ ), hydroxycinnamates (HC) (1.09-12.57 mg/g), jasmonic acid derivatives (JA) (1.99-6.60 mg/g) and dihydrochalcones (DHC) (0.07-4.07 mg/g) (Fig. 2). The average contents of 43 compounds identified (presented in Table 5 in the Appendix) in leaves of hybrid aspens from different competitive statuses and thinning treatment classes are provided in the Table 6 in the Appendix.

The contents of the measured compounds were strongly dependent on the tree's competitive status in all compound classes (Tables 2 and 3). The total contents of different compound groups in competitively advantaged trees were not influenced by the thinning treatment (Table 2). Bivariate correlations based on data pooled by competitive status class suggest that total contents of DHC and SA were negatively correlated with

Table 2 Effects of the thinning treatment $(T)$ and the tree's competitive status (CS dominant or suppressed) on foliar secondary metabolite groups. Significantly different treatment groups (UT un-thinned,

$C$ corridor thinning, $C C$, cross-corridor thinning) are distinguished with different letters (where ' $a$ ' is the group with the greatest mean concentration), based on Tukey's test

\begin{tabular}{|c|c|c|c|c|c|c|c|c|c|c|}
\hline \multirow[t]{2}{*}{ Class of compounds } & \multirow[t]{2}{*}{ Model } & \multicolumn{3}{|c|}{ Factor } & \multicolumn{3}{|c|}{ Dominant trees } & \multicolumn{3}{|c|}{ Suppressed trees } \\
\hline & & $\mathrm{T}$ & $\mathrm{CS}$ & $\mathrm{T} \times \mathrm{CS}$ & UT & $\mathrm{C}$ & $\mathrm{CC}$ & UT & $\mathrm{C}$ & $\mathrm{CC}$ \\
\hline Dihydrochalcones & $* * *$ & $*$ & $* * *$ & $* * *$ & $\mathrm{c}$ & $\mathrm{c}$ & $\mathrm{c}$ & $\mathrm{c}$ & $\mathrm{b}$ & a \\
\hline Flavonoids & $* * *$ & $* * *$ & $* * *$ & $* * *$ & $a b$ & $\mathrm{a}$ & $a b$ & $\mathrm{c}$ & $\mathrm{b}$ & $a b$ \\
\hline Hydroxycinnamates & $* * *$ & ns & $* * *$ & $* * *$ & $\mathrm{a}$ & $\mathrm{a}$ & $a b$ & $\mathrm{~b}$ & $a b$ & $\mathrm{a}$ \\
\hline Jasmonates & $* * *$ & ns & $* * *$ & $* * *$ & $\mathrm{bc}$ & $\mathrm{c}$ & $\mathrm{bc}$ & $\mathrm{a}$ & $a b$ & $\mathrm{bc}$ \\
\hline Salicylates & $* * *$ & ns & $* * *$ & $*$ & $\mathrm{c}$ & $\mathrm{c}$ & $\mathrm{c}$ & $\mathrm{b}$ & $a b$ & a \\
\hline
\end{tabular}

Model—significance of the LMM model after Bonferroni correction for multiple testing $(n=5)$. $n s$ not significant

${ }^{*} p<0.05 ; * *<0.01 ; * * * p<0.001$ 
Table 3 Effects of the thinning treatment $(T)$ and the tree's competitive status (CS, dominant or suppressed) on foliar secondary metabolites. Significantly different groups (UT, un-thinned; $C$, corridor thinning; $C C$, cross-corridor thinning) are distinguished with different letters (where ' $\mathrm{a}$ ' is the group with the greatest mean concentration), based on Tukey's test. Model - significance of the LMM model after Bonferroni correction for multiple testing $(n=43)$. ns - not significant, ${ }^{*} p<0.05, * * p<0.01,{ }^{*} * * p<0.001$

\begin{tabular}{|c|c|c|c|c|c|c|c|c|c|c|}
\hline \multirow[t]{2}{*}{ Compound } & \multirow[t]{2}{*}{ Model } & \multicolumn{3}{|c|}{ Factor } & \multicolumn{3}{|c|}{ Dominant trees } & \multicolumn{3}{|c|}{ Suppressed trees } \\
\hline & & $\mathrm{T}$ & $\mathrm{CS}$ & $\mathrm{T} \times \mathrm{CS}$ & UT & $\mathrm{C}$ & $\mathrm{CC}$ & UT & $\mathrm{C}$ & $\mathrm{CC}$ \\
\hline \multicolumn{11}{|l|}{ Dihydrochalcones } \\
\hline Trihydroxy-methoxydihydrochalcone- $O$-glucoside 1 & $* * *$ & ns & $* * *$ & ns & $\mathrm{b}$ & $\mathrm{b}$ & $\mathrm{b}$ & $\mathrm{a}$ & $\mathrm{a}$ & a \\
\hline Trihydroxy-methoxydihydrochalcone- $O$-glucoside 2 & $* * *$ & ns & $* * *$ & $*$ & $\mathrm{c}$ & $\mathrm{c}$ & $\mathrm{c}$ & $\mathrm{bc}$ & $a b$ & $\mathrm{a}$ \\
\hline Hesperetin dihydrochalcone- $O$-glucoside 1 & $* * *$ & $*$ & $* * *$ & $* * *$ & $\mathrm{~b}$ & $\mathrm{~b}$ & $\mathrm{~b}$ & $\mathrm{~b}$ & $\mathrm{a}$ & $\mathrm{a}$ \\
\hline Hesperetin dihydrochalcone- $O$-glucoside 2 & $* * *$ & ns & $* * *$ & $* * *$ & $\mathrm{~b}$ & $\mathrm{~b}$ & $\mathrm{~b}$ & $\mathrm{~b}$ & $\mathrm{a}$ & $\mathrm{a}$ \\
\hline \multicolumn{11}{|l|}{ Flavonoids } \\
\hline Catechin and epicatechin & $* * *$ & $* * *$ & $* * *$ & $* * *$ & $a b$ & $\mathrm{a}$ & $a b$ & $\mathrm{c}$ & $\mathrm{b}$ & $a b$ \\
\hline (Epi)gallocatechin & $* * *$ & $* * *$ & $* * *$ & $*$ & $\mathrm{a}$ & a & $\mathrm{a}$ & $\mathrm{b}$ & a & a \\
\hline Procyanidin B type & $* * *$ & $* * *$ & $* * *$ & $* * *$ & $\mathrm{ab}$ & $\mathrm{a}$ & $\mathrm{a}$ & $\mathrm{c}$ & $\mathrm{b}$ & $\mathrm{a}$ \\
\hline Quercetin- $O$-pentoside 1 & $* * *$ & $* *$ & $* * *$ & $* * *$ & $a b c$ & $\mathrm{a}$ & $a b$ & $\mathrm{~d}$ & $\mathrm{bc}$ & $\mathrm{c}$ \\
\hline Quercetin- $O$-pentoside 2 & $* * *$ & $* *$ & $* * *$ & $* * *$ & $\mathrm{ab}$ & $\mathrm{a}$ & a & $\mathrm{c}$ & $\mathrm{b}$ & $\mathrm{ab}$ \\
\hline Kaempferol-3-O-galactoside & $* * *$ & $* *$ & $* * *$ & $* * *$ & $a b$ & $\mathrm{a}$ & $\mathrm{ab}$ & $\mathrm{c}$ & $\mathrm{b}$ & $\mathrm{b}$ \\
\hline Kaempferol-3-O-glucoside & $* * *$ & $*$ & $* * *$ & $* * *$ & $\mathrm{ab}$ & $\mathrm{a}$ & $\mathrm{ab}$ & $\mathrm{c}$ & $\mathrm{b}$ & $\mathrm{ab}$ \\
\hline Myricetin- $O$-pentoside & $* * *$ & $* *$ & $* * *$ & $* *$ & $a b$ & $\mathrm{a}$ & $\mathrm{a}$ & $\mathrm{d}$ & $\mathrm{c}$ & $\mathrm{bc}$ \\
\hline Kaempferol-3-O-glucuronide & $* * *$ & $*$ & $*$ & $* * *$ & $\mathrm{ab}$ & $\mathrm{a}$ & $\mathrm{bc}$ & $\mathrm{c}$ & $\mathrm{a}$ & $\mathrm{ab}$ \\
\hline Quercetin-3-O-galacatoside & $* * *$ & $*$ & $* * *$ & $* * *$ & $\mathrm{ab}$ & $\mathrm{a}$ & $\mathrm{ab}$ & $\mathrm{d}$ & $\mathrm{bc}$ & $\mathrm{c}$ \\
\hline Quercetin-3-O-glucoside & $* * *$ & $*$ & $* * *$ & $* * *$ & $\mathrm{ab}$ & $\mathrm{a}$ & $\mathrm{ab}$ & $\mathrm{c}$ & $\mathrm{b}$ & $\mathrm{ab}$ \\
\hline Quercetin-3-O-glucuronide & $* * *$ & $* *$ & $* * *$ & $* * *$ & $a b$ & a & $\mathrm{b}$ & $\mathrm{c}$ & $\mathrm{ab}$ & $\mathrm{ab}$ \\
\hline Myricetin-3-O-galactoside & $\mathrm{ns}$ & - & - & - & - & - & - & - & - & - \\
\hline Myricetin-3-O-glucoside & $* * *$ & $* * *$ & $* * *$ & $* *$ & $\mathrm{abc}$ & $\mathrm{ab}$ & $\mathrm{a}$ & $\mathrm{d}$ & $\mathrm{cd}$ & $\mathrm{bc}$ \\
\hline Myricetin-3-O-glucuronide & $* * *$ & $* * *$ & $* * *$ & $* * *$ & $\mathrm{ab}$ & $\mathrm{a}$ & $\mathrm{ab}$ & $\mathrm{c}$ & $\mathrm{b}$ & $\mathrm{ab}$ \\
\hline Kaempferol- $O$-pentosylhexoside & $* * *$ & ns & $* *$ & $* * *$ & $\mathrm{ab}$ & $\mathrm{ab}$ & $\mathrm{bc}$ & $\mathrm{c}$ & $\mathrm{ab}$ & $\mathrm{a}$ \\
\hline Kaempferol- $O$-rhamnosylhexoside & $* * *$ & ns & ns & $* * *$ & a & $\mathrm{ab}$ & $\mathrm{ab}$ & $\mathrm{b}$ & $\mathrm{ab}$ & $\mathrm{ab}$ \\
\hline Quercetin-3-O-arabinoglucoside & $* * *$ & $*$ & $* * *$ & $* * *$ & a & $\mathrm{a}$ & a & $\mathrm{b}$ & $\mathrm{a}$ & $\mathrm{a}$ \\
\hline Unk flavonoid 1 & $* * *$ & $* * *$ & $* * *$ & $* * *$ & $\mathrm{ab}$ & $\mathrm{a}$ & $\mathrm{bc}$ & $\mathrm{c}$ & $\mathrm{b}$ & $\mathrm{bc}$ \\
\hline Unk flavonoid 2 & ns & - & - & - & - & - & - & - & - & - \\
\hline \multicolumn{11}{|l|}{ Hydroxycinnamates } \\
\hline 5-p-O-coumaroylquinic acid & $* * *$ & ns & ns & $* * *$ & $\mathrm{ab}$ & $\mathrm{ab}$ & $\mathrm{bc}$ & $\mathrm{c}$ & $\mathrm{ab}$ & $\mathrm{a}$ \\
\hline 3-p-O-coumaroylquinic acid & $* * *$ & $* *$ & $* * *$ & $* * *$ & $\mathrm{a}$ & $\mathrm{a}$ & $\mathrm{a}$ & $\mathrm{b}$ & $\mathrm{a}$ & $\mathrm{a}$ \\
\hline cis 3-O-caffeoylquinic acid & $* * *$ & ns & $* * *$ & $* *$ & $\mathrm{a}$ & $\mathrm{a}$ & $\mathrm{ab}$ & $\mathrm{b}$ & $\mathrm{ab}$ & $\mathrm{ab}$ \\
\hline trans 3-O-caffeoylquinic acid & $* * *$ & ns & $* * *$ & $* * *$ & $\mathrm{a}$ & $\mathrm{a}$ & $\mathrm{a}$ & $\mathrm{b}$ & $\mathrm{a}$ & $\mathrm{a}$ \\
\hline 5-O-caffeoylquinic acid & $* * *$ & $*$ & $* * *$ & $* * *$ & $\mathrm{a}$ & a & $\mathrm{a}$ & $\mathrm{b}$ & $\mathrm{a}$ & a \\
\hline 4- $O$-caffeoylquinic acid & $* * *$ & ns & $* * *$ & $* * *$ & $\mathrm{ab}$ & $\mathrm{ac}$ & $\mathrm{ab}$ & $\mathrm{cd}$ & bd & abcd \\
\hline \multicolumn{11}{|l|}{ Jasmonates } \\
\hline Hydroxyl-dihydrojasmonic acids & $* * *$ & ns & $* * *$ & ns & $\mathrm{a}$ & $\mathrm{a}$ & $\mathrm{a}$ & $\mathrm{b}$ & $\mathrm{b}$ & $\mathrm{b}$ \\
\hline Hydroxyjasmonyl sulfate & $* * *$ & ns & $* * *$ & $*$ & $\mathrm{~b}$ & $\mathrm{ab}$ & $a b$ & $\mathrm{a}$ & $a b$ & $a b$ \\
\hline Unidentified jasmonate & $\mathrm{ns}$ & - & - & - & - & - & - & - & - & - \\
\hline Hydroxyjasmonic acid glucoside & $* * *$ & ns & $* * *$ & ns & $\mathrm{b}$ & $\mathrm{b}$ & $\mathrm{b}$ & $\mathrm{a}$ & a & a \\
\hline \multicolumn{11}{|l|}{ Salicylates } \\
\hline Salicin & $* * *$ & ns & $* * *$ & ns & $\mathrm{b}$ & $\mathrm{b}$ & $\mathrm{b}$ & $\mathrm{a}$ & a & $\mathrm{a}$ \\
\hline Salicortin & $* * *$ & ns & $* * *$ & ns & $\mathrm{b}$ & $\mathrm{b}$ & $\mathrm{b}$ & $\mathrm{a}$ & $\mathrm{a}$ & $\mathrm{a}$ \\
\hline Grandidentatin 1 & $* * *$ & $* * *$ & $* * *$ & $* *$ & $\mathrm{c}$ & $\mathrm{bc}$ & $\mathrm{bc}$ & $\mathrm{b}$ & $\mathrm{a}$ & $\mathrm{a}$ \\
\hline Grandidentatin 2 & $* * *$ & $*$ & $* * *$ & $* * *$ & $\mathrm{c}$ & $\mathrm{bc}$ & $\mathrm{bc}$ & $\mathrm{b}$ & a & $\mathrm{a}$ \\
\hline Tremuloidin FA adduct & $* * *$ & $* *$ & $* * *$ & ns & $\mathrm{c}$ & $\mathrm{d}$ & $\mathrm{cd}$ & $\mathrm{a}$ & $\mathrm{b}$ & $\mathrm{ab}$ \\
\hline Salicortin FA adduct & $* * *$ & ns & $* * *$ & ns & $\mathrm{b}$ & $\mathrm{b}$ & $\mathrm{b}$ & $\mathrm{a}$ & $\mathrm{a}$ & $\mathrm{a}$ \\
\hline Tremulacin & $* * *$ & ns & $* * *$ & ns & $\mathrm{b}$ & $\mathrm{b}$ & $\mathrm{b}$ & $\mathrm{a}$ & a & $\mathrm{a}$ \\
\hline \multicolumn{11}{|l|}{ Unknowns } \\
\hline Unk1 & ns & - & - & - & - & - & - & - & - & - \\
\hline Unk2 & $* * *$ & ns & $* * *$ & ns & $\mathrm{b}$ & $\mathrm{b}$ & $\mathrm{b}$ & $\mathrm{a}$ & $\mathrm{a}$ & $\mathrm{a}$ \\
\hline
\end{tabular}

Model—significance of the LMM model after Bonferroni correction for multiple testing $(n=43)$. $n s$ not significant

${ }^{*} p<0.05 ; * * p<0.01 ; * * * p<0.001$ 
Table 4 Linear correlations between secondary metabolite concentrations

\begin{tabular}{llllllrr}
\hline $\begin{array}{l}\text { Class of com- } \\
\text { pounds }\end{array}$ & $\begin{array}{l}\text { Tree's competi- } \\
\text { tive status }\end{array}$ & \multicolumn{1}{l}{ Height } & \multicolumn{1}{l}{ L } & \multicolumn{1}{l}{ LWA } & \multicolumn{1}{l}{$[\mathrm{N}]$} & \multicolumn{1}{l}{$[\mathrm{P}]$} & {$[\mathrm{K}]$} \\
\hline DHC & Dominant & -0.58 & -0.12 & -0.11 & 0.13 & 0.25 & -0.24 \\
FLA & Dominant & 0.31 & -0.32 & 0.55 & -0.73 & -0.57 & 0.02 \\
HC & Dominant & -0.13 & 0.15 & -0.14 & 0.07 & 0.35 & 0.11 \\
JA & Dominant & -0.02 & 0.30 & -0.30 & 0.52 & 0.53 & -0.34 \\
SA & Dominant & -0.57 & -0.23 & 0.03 & 0.02 & 0.16 & -0.24 \\
DHC & Suppressed & -0.33 & -0.63 & 0.76 & -0.64 & -0.47 & -0.70 \\
FLA & Suppressed & -0.18 & -0.67 & 0.86 & -0.82 & -0.66 & -0.78 \\
HC & Suppressed & -0.01 & -0.60 & 0.77 & -0.65 & -0.50 & -0.73 \\
JA & Suppressed & 0.43 & 0.62 & -0.70 & 0.64 & 0.70 & 0.69 \\
SA & Suppressed & -0.26 & -0.50 & 0.62 & -0.66 & -0.44 & -0.60 \\
\hline
\end{tabular}

( $S A$ salicylates, FLA flavonoids, $H C$ hydroxycinnamates, $J A$ jasmonates, $D H C$ dihydrochalcones) of dominant and suppressed trees and model tree height, stand basal area $(G)$, leaf weight per area $(L W A)$ and macronutrient concentrations

Significant $(p<0.05)$ correlations are in italics the height of competitively advantaged trees (Table 4). The nonsignificant correlations between compounds and stand basal area $(G)$ support the invariable secondary metabolism of advantaged trees, irrespective of the thinning intensity (i.e., crowding).

The thinning treatment most strongly influenced the competitively suppressed trees-DHC and FLA were significantly lower in the un-thinned control compared to both corridor thinning treatments (Table 2, Fig. 2). The levels of HC and SA differed between the cross-corridor and the un-thinned control treatment. The JA concentration in suppressed trees responded in the opposite direction, being the lowest in the cross-corridor group and the highest in the control.

Model tree height and DBH depended significantly on the tree competitive status (CS) but did not vary among the thinning treatments within a CS class (Table 1). Foliar macronutrient contents and LWA were affected by both CS as well as thinning treatment (Table 1). Stand basal area $(G)$ differed significantly $(p<0.001)$ among the treatments, with average values of $15.4 \pm 1.52 \mathrm{~m}^{2} \mathrm{ha}^{-1}$ in the un-thinned control, $8.5 \pm 0.46 \mathrm{~m}^{2} \mathrm{ha}^{-1}$ in corridor thinning and $3.9 \pm 0.34 \mathrm{~m}^{2} \mathrm{ha}^{-1}$ in cross-corridor thinning. Moderate to strong negative correlations were observed between $G$ and contents of DHC, FLA, HC and SA in suppressed trees (Table 4). The content of JA was in moderate positive correlation with $G$ and height of suppressed trees. Foliar macronutrients were significantly correlated with measured secondary compounds primarily in suppressed trees. Foliar [N], [P] and [K] levels of suppressed trees were negatively correlated with all compound classes except JA, where the respective relationships were positive. In dominant trees, foliar $[\mathrm{N}]$ and $[\mathrm{P}]$ were positively correlated with JA and negatively with FLA; these relations were slightly weaker than in suppressed trees.

\section{Discussion}

\subsection{Exposure to irradiance affects foliar metabolite profiles of hybrid aspens on a fertile site}

We present the first comprehensive study of the secondary metabolite profile of hybrid aspen leaves. Significant changes in the leaf secondary metabolite profile were detected, which were related to tree competitive status and forest management practices aimed to regulate stand density. The salicylate compound grandidentatin and its isomer, which have previously been found in some other species of the Salicaceae family (Pearl and Darling 1962, 1970; Si et al. 2011; Snyder et al. 2015; Jervis et al. 2015), were for the first time tentatively identified in hybrid aspen leaves.

Contrarily to our hypothesis, the expected decreased level of competition stress under improved light and nutrition conditions in the thinning treatments did not result in a lower content of foliar secondary metabolites in neither dominant nor suppressed trees. In both corridor thinning treatments ( $\mathrm{C}$ and $\mathrm{CC}$ ), competitively suppressed trees had higher levels of SA and DHC compared to dominant trees in all treatments, while contents of FLA, HC and JA in suppressed trees of C and CC treatments were at comparable levels with dominant trees. The only class of compounds in suppressed trees which differed significantly between the two thinning treatments was DHC, which was higher in the cross-corridor than in the corridor thinning.

Our study site lies on Retic Umbrisol, which is a fertile soil with high nutrient pools and good water-holding properties (Lutter et al. 2017). Therefore, dominant trees 
were growing in a high-resource environment, while suppressed tree growth was obviously more limited by shading of overtopping trees than by insufficient nutrient and water supply. The observed lower levels of SA, DHC and JA in dominant trees compared to suppressed trees are in accordance with the growth-differentiation balance hypothesis, which states that in high-resource environments, the assimilated $\mathrm{C}$ is allocated to growth at the expense of defence mechanisms (Herms and Mattson 1992). The findings of the current study are congruent with Ruuhola and Julkunen-Tiito (2003), who showed that inducing the synthesis of SAs can also result in lower above-ground biomass accumulation for Salix pentandra.

Generally, dominant trees had similar levels of metabolites in all treatments. At the same time, the metabolic profiles of suppressed trees differed significantly between the treatments. At the most crowded conditions, in the un-thinned control, FLA and HC in suppressed trees were the lowest (Fig. 2). Flavonoids and hydroxycinnamates play an important role in shielding the tree leaves from UV irradiation (Burchard et al. 2000; Groenbaek et al. 2019; Valle et al. 2020), which was obviously much less intensive in the shady environment where the suppressed control group trees were growing. In suppressed trees, increases in FLA and $\mathrm{HC}$ contents go hand in hand with increases in the extent of thinning, supporting the association between UV radiation and FLA and HC production (Lavola 1998; Kotilainen et al. 2008; Morales et al. 2010; Nissinen et al. 2017).

DHCs belong to the class of flavonoids as well, but unlike major flavonoids (e.g. quercetin, myricetin, kaempferol), they have an open-chain structure which gives them the capacity to exhibit great antioxidant potential despite their relatively low content in plants (Nakamura et al. 2003; Dugé de Bernonville et al. 2010; Ibdah et al. 2018; Li et al. 2018). It appears that in a dense hybrid aspen coppice, competitively suppressed residual trees were put under increasing oxidative stress with the increase of thinning intensity while dominant residual trees exhibited no signs of considerable stress at all.

Four of the five classes of metabolites analysed were phenolic compounds (SA, FLA, HC and DHC) that are all derived from the phenylpropanoid pathway which requires the amino acid phenylalanine as a precursor (Dixon and Paiva 1995). JA, on the other hand, are derived from $\alpha$-linolenic acid present in chloroplast membranes and are the first signalling molecules synthesised in response to various stresses (Wasternack and Strnad 2018). JA act through inhibiting plant growth by inducing the enzyme phenylalanine ammonia-lyase (PAL) that separates primary and secondary metabolism resulting in more resources allocated to the phenolic compound production (Dixon and Paiva 1995; Huang et al. 2017). JA are mostly associated with wounding and pathogen attack, but there is also evidence that oxidative stress caused by UV-B irradiation can induce the synthesis of JA (Svyatyna and Riemann 2012; Wasternack and Strnad 2018). While JA promote the synthesis of SA among other phenolic compounds by inducing PAL, SA in turn inhibits the synthesis of JA by blocking the linolenic acid pathway (Doares et al. 1995; Khan and Khan 2013; Per et al. 2018). SA blocking the synthesis of JA explains well the observed opposite correlations between phenolics and JA content in suppressed residual trees. Also, it suggests that the content of JA is inherently higher in suppressed trees than in dominant trees, since the higher content of SA suppresses the JA synthesis in the two corridor thinning treatments.

\subsection{Post-thinning changes in the foliar metabolite profile reflect the altered root: shoot ratio of re-sprouted hybrid aspens}

Early thinning of a young aspen coppice stand could be considered as a wounding of this root-connected clonal organism. An increase in the SA content in response to wounding has been shown in Salix spp. (Ruuhola et al. 2001), but it must be considered that the response to wounding is shortterm, whereas the samples in the current study were collected in the middle of the second growing season after the thinning. It has been shown that the content of SA can also be enhanced by increased UV radiation (Warren et al. 2003; Nissinen et al. 2017), which would explain the raise of SA with thinning, but suppressed trees had higher levels of SA also in the control group. Controversially, Rhodes et al. (2016) found no impact of tree size on the leaf content of phenolic glucosides (mainly SA: tremulacin and salicortin) in Populus tremuloides, while there was a clear difference in SA content in the current study. This could be because Rhodes et al. (2016) classified trees based on stem diameter but not directly on trees competitive status within the local neighbourhood as in our study. In addition, Rhodes et al. (2016) sampled trees from older and sparser stands, where the negative impact from intraspecific competition was apparently weaker than in young and dense aspen coppices.

In a young aspen coppice forest interconnected through the root system, disturbance of one tree can trigger a physiological response in its neighbouring trees (Baret and DesRochers 2011). Moreover, defoliation of dominant trees has a greater effect on their suppressed neighbours than vice-versa (Baret and DesRochers 2011). In our study, thinning resulted in significantly lower leaf area index (reduction was $47 \%$ in the corridor and $78 \%$ 
in the cross-corridor treatment) compared to un-thinned stand (Hepner et al. 2020), but it is likely that the roots of the cut trees remained alive (DesRochers and Lieffers 2001). Consequently, the maintenance cost of the root system for the remaining trees increased as they lost many root-connected neighbours, whereas the metabolic profiles revealed that post-thinning stress response was characteristic to suppressed residual trees. Knowing that suppressed trees have a smaller photosynthetic leaf area than dominant trees, thinning would more significantly affect the suppressed trees' physiology, as they have to supply the root system with photosynthates under the conditions of an even lower photosynthetic capacity than prior to thinning. Accordingly, dominant trees leaf growth efficiency (aboveground woody biomass produced per unit of leaf area) was almost twofold compared to the stand average in all treatments of our study (Hepner et al. 2020).

As we investigated a coppiced aspen stand, we lack information about the genotypes of the individual sample trees. The initial hybrid aspen plantation consisted of various genotypes with random planting when it was first established. Generally, the secondary metabolite profile of Populus spp. is highly dependent on the genotype (Bandau et al. 2015; Hamanishi et al. 2015; Popović et al. 2016). As suppressed and dominant trees (root-sprout originated hybrid aspens) were chosen as side-by-side pairs, it is quite likely that they shared the same parent tree root system and belonged to the same genotype. To avoid apparent spatial autocorrelation (arising from genotype and microsite), we included the sampling area as a random effect in our LMM analysis. Therefore, it can be stated with a high degree of plausibility that trees reacted differently to thinning treatment, depending on their competitive status, even despite the possible random sources of variation caused by genotype and microsite.

A higher content of secondary metabolites did not result in a significantly lower growth of trees in thinning treatments, although there was a tendency in mean tree height to decrease with increasing thinning intensity. As thinning is aimed to improve the availability of resources, we would expect to see a rise in foliar macronutrient content, but instead observed a decrease in foliar $[\mathrm{N}],[\mathrm{P}]$ and $[\mathrm{K}]$ levels in both dominant as well as suppressed trees. It should be noted that we performed the foliar chemistry analysis in the second post-thinning year, when the trees had already had some time to acclimate to the altered environment. Generally, northern deciduous trees display fast leaf area and growth recovery responses to thinning (Rytter 2013), while the foliar secondary metabolite contents in hybrid aspen coppice stand infer that such integrated clonal tree recovery from losing neighbour trees is not as prompt as would be expected by anatomical measures. Although the FLA and $\mathrm{HC}$ content in suppressed trees after thinning is now comparable to that of dominant trees due to better light conditions, the almost fourfold higher SA and DHC content indicates that the trees have not yet overcome the stress that was caused by thinning.

\subsection{Conclusions}

For a more efficient redistribution of resources during the early management of aspen coppice forests, less intensive early thinning (resulting in a less drastic reduction in photosynthetic leaf area), with ample time for leaf area recovery, or corridor thinning followed by traditional selective thinning from below could be considered as alternatives.

The secondary metabolism of competitively dominant trees was not affected by thinning; hence, overtopping trees were growing under similar resource supply conditions irrespective of stand density. The secondary metabolism of suppressed trees showed the strongest response to thinning, which was partly related to an altered exposure to irradiance and partly to the increased maintenance cost per leaf area due to diminished support from root-connected neighbours. Several changes in suppressed trees' post-thinning metabolite profiles indicate increased stress levels. Although the increased SA content in suppressed trees enhances resistance to herbivory and pathogens it is an additional cost at the expense of tree growth. To increase biomass production, such suppressed trees should be thinned out. Further studies are, however, needed to clarify the duration of such impact within a longer time span after thinning, also including other species than hybrid aspen.

Funding This work was supported by the Estonian Research Council (grant PSG7) and by institutional research funding IUT (grants IUT21-4 and IUT34-9) of the Estonian Ministry of Education and Research.

Data availability The datasets generated and/or analyzed during the current study are available in the Zenodo repository, https://doi. org/10.5281/zenodo.4095450.

\section{Compliance with ethical standards}

Conflict of interest The authors declare that they have no conflict of interest. 


\section{Appendix}

Table 5 Retention times $\left(t_{R}\right)$, mass-to-charge ratios $(\mathrm{m} / \mathrm{z})$ and mass differences of compounds detected in methanolic extracts of hybrid aspen leaves

\begin{tabular}{|c|c|c|c|c|}
\hline & $t_{R}(\min )$ & $\begin{array}{l}\text { Monoisotopic } \\
m / z \text { [M-H }]^{-}\end{array}$ & $\begin{array}{l}\text { Observed } \\
m / z[\mathrm{M}-\mathrm{H}]^{-}\end{array}$ & $\begin{array}{l}\text { Mass differ- } \\
\text { ence (ppm) }\end{array}$ \\
\hline \multicolumn{5}{|l|}{ Dihydrochalcones } \\
\hline Hesperetin dihydrochalcone- $O$-glucoside 1 & 41.4 & 465.1402 & 465.1392 & -2.1 \\
\hline Hesperetin dihydrochalcone- $O$-glucoside 2 & 44.4 & 465.1402 & 465.1392 & -2.1 \\
\hline Trihydroxy-methoxydihydrochalcone- $O$-glucoside 1 & 53.9 & 449.1453 & 449.1453 & 0.0 \\
\hline Trihydroxy-methoxydihydrochalcone- $O$-glucoside 2 & 57.1 & 449.1453 & 449.1453 & 0.0 \\
\hline \multicolumn{5}{|l|}{ Flavonoids } \\
\hline (Epi)gallocatechin & 5.9 & 305.0667 & 305.0665 & -0.7 \\
\hline Procyanidin B type & 13.6 & 577.1351 & 577.1339 & -2.1 \\
\hline Catechin and epicatechin & 14.3 & 289.0718 & 289.0718 & 0.0 \\
\hline Unk flavonoid 1 & 26.8 & & 623.1254 & \\
\hline Myricetin-3-O-glucuronide & 29.1 & 493.0624 & 493.0639 & 3.0 \\
\hline Myricetin-3-O-galactoside & 29.3 & 479.0831 & 479.0845 & 3.1 \\
\hline Myricetin-3-O-glucoside & 30.0 & 479.0831 & 479.0850 & 4.0 \\
\hline Unk flavonoid 2 & 31.2 & & 623.1254 & \\
\hline Quercetin-3-O-arabinoglucoside & 32.2 & 595.1305 & 595.1327 & 3.8 \\
\hline Myricetin- $O$-pentoside & 33.0 & 449.0725 & 449.0730 & 1.2 \\
\hline Quercetin-3-O-galacatoside & 34.2 & 463.0882 & 463.0895 & 2.8 \\
\hline Quercetin-3-O-glucuronide & 34.9 & 477.0675 & 477.0696 & 4.4 \\
\hline Quercetin-3-O-glucoside & 35.5 & 463.0882 & 463.0894 & 2.6 \\
\hline Kaempferol-O-rhamnosylhexoside & 36.4 & 593.1512 & 593.1533 & 3.5 \\
\hline Kaempferol-O-pentosylhexoside & 36.6 & 579.1355 & 579.1380 & 4.3 \\
\hline Quercetin- $O$-pentoside 1 & 37.5 & 433.0776 & 433.0786 & 2.3 \\
\hline Kaempferol-3-O-galactoside & 38.0 & 447.0933 & 447.0950 & 3.8 \\
\hline Quercetin- $O$-pentoside 2 & 38.8 & 433.0776 & 433.0789 & 3.0 \\
\hline Kaempferol-3-O-glucuronide & 39.8 & 461.0725 & 461.0730 & 1.1 \\
\hline Kaempferol-3-O-glucoside & 40.1 & 447.0933 & 447.0942 & 2.0 \\
\hline \multicolumn{5}{|l|}{ Hydroxycinnamates } \\
\hline cis 3-O-caffeoylquinic acid & 8.8 & 353.0878 & 353.0883 & 1.3 \\
\hline trans 3-O-caffeoylquinic acid & 9.6 & 353.0878 & 353.0867 & -3.1 \\
\hline 5-p-O-coumaroylquinic acid & 12.3 & 337.0929 & 337.0923 & -1.8 \\
\hline 3-p-O-coumaroylquinic acid & 13.2 & 337.0929 & 337.0917 & -3.6 \\
\hline 5-O-caffeoylquinic acid & 16.5 & 353.0878 & 353.0872 & -1.7 \\
\hline 4-O-caffeoylquinic acid & 18.1 & 353.0878 & 353.0871 & -2.0 \\
\hline \multicolumn{5}{|l|}{ Jasmonates } \\
\hline Hydroxyjasmonyl sulfate & 18.7 & 305.0700 & 305.0695 & -1.6 \\
\hline Hydroxyjasmonic acid glucoside & 23.3 & 387.1661 & 387.1669 & 2.1 \\
\hline Unidentified jasmonate & 43.6 & 373.1868 & 373.1879 & 2.9 \\
\hline Hydroxyl-dihydrojasmonic acid 1 & 63.3 & 227.1289 & 227.1297 & 3.5 \\
\hline Hydroxyl-dihydrojasmonic acid 2 & 66.4 & 227.1289 & 227.1293 & 1.8 \\
\hline \multicolumn{5}{|l|}{ Salicylates } \\
\hline Salicin & 8.5 & 331.1035 & 331.1046 & 3.3 \\
\hline Salicortin & 31.2 & 423.1297 & 423.1315 & 4.3 \\
\hline Salicortin FA adduct & 31.3 & 469.1351 & 469.1372 & 4.5 \\
\hline Grandidentatin 1 & 45.7 & 423.1661 & 423.1679 & 4.3 \\
\hline Tremuloidin FA adduct & 48.4 & 435.1297 & 435.1316 & 4.4 \\
\hline Grandidentatin 2 & 49.4 & 423.1661 & 423.1678 & 4.0 \\
\hline Tremulacin & 64.9 & 527.1559 & 527.1584 & 4.7 \\
\hline \multicolumn{5}{|l|}{ Unknown compounds } \\
\hline Unk1 & 41.9 & & 477.1038 & \\
\hline Unk2 & 51.7 & & 465.1391 & \\
\hline
\end{tabular}


Table 6 Content $(m e a n \pm S E)$ of identified compounds $\left(\mathrm{mg} \mathrm{g}^{-1}\right)$ in leaves of dominant and suppressed hybrid aspens in different thinning treatments

\begin{tabular}{|c|c|c|c|c|c|c|}
\hline \multirow[t]{2}{*}{ Compound } & \multicolumn{3}{|l|}{ Dominant trees } & \multicolumn{3}{|c|}{ Suppressed trees } \\
\hline & UT & $\mathrm{C}$ & $\mathrm{CC}$ & UT & $\mathrm{C}$ & $\mathrm{CC}$ \\
\hline \multicolumn{7}{|l|}{ Dihydrochalcones } \\
\hline Hesperetin dihydrochalcone- $O$-glucoside 1 & $0.12 \pm 0.01$ & $0.12 \pm 0.01$ & $0.10 \pm 0.02$ & $0.08 \pm 0.01$ & $0.23 \pm 0.02$ & $0.36 \pm 0.02$ \\
\hline Hesperetin dihydrochalcone- $O$-glucoside 2 & $0.06 \pm 0.01$ & $0.06 \pm 0.01$ & $0.05 \pm 0.01$ & $0.07 \pm 0.01$ & $0.18 \pm 0.02$ & $0.26 \pm 0.03$ \\
\hline Trihydroxy-methoxydihydrochalcone- $O$-glucoside 1 & $0.09 \pm 0.02$ & $0.07 \pm 0.01$ & $0.10 \pm 0.02$ & $0.40 \pm 0.05$ & $0.59 \pm 0.13$ & $0.88 \pm 0.18$ \\
\hline Trihydroxy-methoxydihydrochalcone- $O$-glucoside 2 & $0.22 \pm 0.03$ & $0.20 \pm 0.03$ & $0.26 \pm 0.05$ & $0.37 \pm 0.05$ & $0.84 \pm 0.13$ & $1.31 \pm 0.13$ \\
\hline \multicolumn{7}{|l|}{ Flavonoids } \\
\hline (Epi)gallocatechin & $0.23 \pm 0.04$ & $0.43 \pm 0.09$ & $0.40 \pm 0.09$ & $0.12 \pm 0.09$ & $0.19 \pm 0.06$ & $0.27 \pm 0.05$ \\
\hline Procyanidin B type & $1.10 \pm 0.08$ & $1.40 \pm 0.13$ & $1.74 \pm 0.13$ & $0.38 \pm 0.09$ & $0.91 \pm 0.18$ & $1.84 \pm 0.21$ \\
\hline Catechin and epicatechin & $1.83 \pm 0.26$ & $3.02 \pm 0.34$ & $3.09 \pm 0.22$ & $0.43 \pm 0.15$ & $1.99 \pm 0.46$ & $3.16 \pm 0.42$ \\
\hline Unk flavonoid 1 & $0.30 \pm 0.01$ & $0.43 \pm 0.05$ & $0.24 \pm 0.01$ & $0.18 \pm 0.01$ & $0.32 \pm 0.03$ & $0.22 \pm 0.02$ \\
\hline Myricetin-3-O-glucuronide & $0.76 \pm 0.06$ & $0.98 \pm 0.07$ & $0.93 \pm 0.06$ & $0.40 \pm 0.01$ & $0.70 \pm 0.10$ & $0.80 \pm 0.04$ \\
\hline Myricetin-3-O-galactoside & $0.61 \pm 0.05$ & $0.59 \pm 0.09$ & $0.60 \pm 0.06$ & $0.69 \pm 0.08$ & $0.76 \pm 0.07$ & $0.83 \pm 0.06$ \\
\hline Myricetin-3-O-glucoside & $0.78 \pm 0.08$ & $0.98 \pm 0.11$ & $1.00 \pm 0.08$ & $0.36 \pm 0.01$ & $0.59 \pm 0.09$ & $0.75 \pm 0.05$ \\
\hline Unk flavonoid 2 & $0.54 \pm 0.03$ & $0.65 \pm 0.04$ & $0.43 \pm 0.02$ & $0.33 \pm 0.05$ & $0.61 \pm 0.05$ & $0.39 \pm 0.05$ \\
\hline Quercetin-3-O-arabinoglucoside & $0.92 \pm 0.09$ & $0.99 \pm 0.10$ & $0.91 \pm 0.12$ & $0.42 \pm 0.09$ & $0.88 \pm 0.12$ & $1.16 \pm 0.10$ \\
\hline Myricetin- $O$-pentoside & $0.75 \pm 0.03$ & $0.95 \pm 0.05$ & $0.91 \pm 0.04$ & $0.35 \pm 0.01$ & $0.55 \pm 0.05$ & $0.63 \pm 0.05$ \\
\hline Quercetin-3-O-galacatoside & $0.80 \pm 0.02$ & $0.98 \pm 0.04$ & $0.77 \pm 0.03$ & $0.21 \pm 0.03$ & $0.56 \pm 0.06$ & $0.46 \pm 0.04$ \\
\hline Quercetin-3-O-glucuronide & $2.02 \pm 0.05$ & $2.51 \pm 0.08$ & $1.93 \pm 0.03$ & $1.44 \pm 0.08$ & $2.26 \pm 0.08$ & $2.06 \pm 0.04$ \\
\hline Quercetin-3-O-glucoside & $0.68 \pm 0.04$ & $0.83 \pm 0.06$ & $0.71 \pm 0.05$ & $0.21 \pm 0.04$ & $0.58 \pm 0.07$ & $0.76 \pm 0.05$ \\
\hline Kaempferol- $O$-rhamnosylhexoside & $0.12 \pm 0.01$ & $0.10 \pm 0.02$ & $0.07 \pm 0.01$ & $0.07 \pm 0.01$ & $0.10 \pm 0.01$ & $0.10 \pm 0.01$ \\
\hline Kaempferol- $O$-pentosylhexoside & $0.11 \pm 0.01$ & $0.13 \pm 0.01$ & $0.09 \pm 0.01$ & $0.06 \pm 0.01$ & $0.11 \pm 0.01$ & $0.13 \pm 0.01$ \\
\hline Quercetin- $O$-pentoside 1 & $0.47 \pm 0.02$ & $0.62 \pm 0.03$ & $0.51 \pm 0.03$ & $0.09 \pm 0.01$ & $0.32 \pm 0.04$ & $0.34 \pm 0.05$ \\
\hline Kaempferol-3-O-galactoside & $0.07 \pm 0.004$ & $0.09 \pm 0.01$ & $0.07 \pm 0.01$ & $0.02 \pm 0.002$ & $0.05 \pm 0.01$ & $0.05 \pm 0.01$ \\
\hline Quercetin- $O$-pentoside 2 & $0.18 \pm 0.01$ & $0.24 \pm 0.01$ & $0.21 \pm 0.02$ & $0.03 \pm 0.004$ & $0.12 \pm 0.02$ & $0.16 \pm 0.02$ \\
\hline Kaempferol-3-O-glucuronide & $0.68 \pm 0.03$ & $0.95 \pm 0.07$ & $0.52 \pm 0.02$ & $0.40 \pm 0.04$ & $0.88 \pm 0.06$ & $0.71 \pm 0.03$ \\
\hline Kaempferol-3-O-glucoside & $0.15 \pm 0.01$ & $0.19 \pm 0.03$ & $0.16 \pm 0.01$ & $0.05 \pm 0.01$ & $0.12 \pm 0.02$ & $0.18 \pm 0.01$ \\
\hline \multicolumn{7}{|l|}{ Hydroxycinnamates } \\
\hline cis 3-O-caffeoylquinic acid & $2.04 \pm 0.37$ & $2.58 \pm 0.28$ & $1.91 \pm 0.20$ & $0.60 \pm 0.10$ & $1.96 \pm 0.31$ & $2.04 \pm 0.30$ \\
\hline trans 3-O-caffeoylquinic acid & $3.15 \pm 0.30$ & $3.48 \pm 0.25$ & $2.75 \pm 0.23$ & $1.00 \pm 0.14$ & $2.70 \pm 0.31$ & $2.74 \pm 0.32$ \\
\hline 5-p-O-coumaroylquinic acid & $0.56 \pm 0.09$ & $0.77 \pm 0.11$ & $0.49 \pm 0.06$ & $0.26 \pm 0.03$ & $0.86 \pm 0.12$ & $0.85 \pm 0.10$ \\
\hline 3-p-O-coumaroylquinic acid & $1.28 \pm 0.13$ & $1.62 \pm 0.14$ & $1.27 \pm 0.09$ & $0.36 \pm 0.06$ & $1.28 \pm 0.17$ & $1.37 \pm 0.11$ \\
\hline 5- $O$-caffeoylquinic acid & $0.45 \pm 0.07$ & $0.84 \pm 0.13$ & $0.56 \pm 0.08$ & $0.18 \pm 0.06$ & $0.60 \pm 0.16$ & $0.67 \pm 0.12$ \\
\hline 4- $O$-caffeoylquinic acid & $0.90 \pm 0.18$ & $0.59 \pm 0.05$ & $0.74 \pm 0.10$ & $0.21 \pm 0.03$ & $0.31 \pm 0.05$ & $0.63 \pm 0.11$ \\
\hline \multicolumn{7}{|l|}{ Jasmonates } \\
\hline Hydroxyjasmonyl sulfate & $1.10 \pm 0.08$ & $0.86 \pm 0.10$ & $0.84 \pm 0.09$ & $2.39 \pm 0.30$ & $1.32 \pm 0.22$ & $0.96 \pm 0.11$ \\
\hline Hydroxyjasmonic acid glucoside & $1.84 \pm 0.06$ & $1.72 \pm 0.09$ & $1.67 \pm 0.07$ & $2.48 \pm 0.10$ & $2.27 \pm 0.15$ & $1.96 \pm 0.06$ \\
\hline Unidentified jasmonate & $0.23 \pm 0.01$ & $0.22 \pm 0.02$ & $0.22 \pm 0.01$ & $0.22 \pm 0.01$ & $0.20 \pm 0.02$ & $0.20 \pm 0.01$ \\
\hline Hydroxyl-dihydrojasmonic acids & $0.18 \pm 0.01$ & $0.15 \pm 0.01$ & $0.17 \pm 0.01$ & $0.09 \pm 0.01$ & $0.10 \pm 0.01$ & $0.09 \pm 0.01$ \\
\hline \multicolumn{7}{|l|}{ Salicylates } \\
\hline Salicin & $1.40 \pm 0.18$ & $0.83 \pm 0.11$ & $1.29 \pm 0.19$ & $3.74 \pm 0.33$ & $3.14 \pm 0.28$ & $3.58 \pm 0.21$ \\
\hline Salicortin & $1.67 \pm 0.40$ & $2.57 \pm 0.47$ & $2.29 \pm 0.63$ & $3.67 \pm 0.53$ & $7.47 \pm 0.86$ & $9.69 \pm 0.95$ \\
\hline Salicortin FA adduct & $4.76 \pm 0.94$ & $6.99 \pm 1.07$ & $6.05 \pm 1.30$ & $9.04 \pm 1.06$ & $16.36 \pm 1.49$ & $19.24 \pm 1.49$ \\
\hline Grandidentatin 1 & $0.22 \pm 0.02$ & $0.26 \pm 0.04$ & $0.29 \pm 0.04$ & $0.63 \pm 0.26$ & $0.98 \pm 0.09$ & $1.50 \pm 0.08$ \\
\hline Tremuloidin FA adduct & $3.10 \pm 0.50$ & $0.95 \pm 0.13$ & $2.27 \pm 0.51$ & $9.71 \pm 0.74$ & $6.96 \pm 0.77$ & $7.24 \pm 0.62$ \\
\hline Grandidentatin 2 & $0.22 \pm 0.02$ & $0.23 \pm 0.03$ & $0.24 \pm 0.04$ & $0.39 \pm 0.05$ & $0.89 \pm 0.14$ & $1.25 \pm 0.15$ \\
\hline Tremulacin & $8.34 \pm 1.39$ & $9.95 \pm 1.46$ & $12.01 \pm 2.18$ & $21.09 \pm 2.10$ & $29.46 \pm 2.34$ & $32.95 \pm 1.97$ \\
\hline Total content of secondary metabolites & $45.07 \pm 3.76$ & $52.12 \pm 4.02$ & $50.88 \pm 4.98$ & $63.21 \pm 4.80$ & $91.30 \pm 5.96$ & $104.75 \pm 5.83$ \\
\hline
\end{tabular}

$U T$ un-thinned, $C$ corridor thinning, $C C$ cross-corridor thinning 


\section{References}

Bandau F, Decker VHG, Gundale MJ, Albrectsen BR (2015) Genotypic tannin levels in Populus tremula impact the way nitrogen enrichment affects growth and allocation responses for some traits and not for others. PLoS ONE 10:e0140971. https://doi.org/10.1371/ journal.pone.0140971

Baret M, DesRochers A (2011) Root connections can trigger physiological responses to defoliation in nondefoliated aspen suckers. Botany 89:753-761. https://doi.org/10.1139/b11-062

Burchard P, Bilger W, Weissenböck G (2000) Contribution of hydroxycinnamates and flavonoids to epidermal shielding of UV-A and UV-B radiation in developing rye primary leaves as assessed by ultravioletinduced chlorophyll fluorescence measurements. Plant Cell Environ 23:1373-1380. https://doi.org/10.1046/j.1365-3040.2000.00633.x

Chen F, Liu C-J, Tschaplinski TJ, Zhao N (2009) Genomics of secondary metabolism in Populus: Interactions with biotic and abiotic environments. Crit Rev Plant Sci 28:375-392. https://doi. org/10.1080/07352680903241279

Desprez-Loustau M-L, Aguayo J, Dutech C, Hayden KJ, Husson C, Jakushkin B, Marçais B, Piou D, Robin C, Vacher C (2016) An evolutionary ecology perspective to address forest pathology challenges of today and tomorrow. Ann For Sci 73:45-67. https://doi. org/10.1007/s13595-015-0487-4

DesRochers A, Lieffers VJ (2001) The coarse-root system of mature Populus tremuloides in declining stands in Alberta, Canada. J Veg Sci 12:355-360. https://doi.org/10.2307/3236849

Dixon R, Paiva N (1995) Stress-induced phenylpropanoid metabolism. Plant Cell 7:1085-1097

Doares SH, Narvaez-Vasquez J, Conconi A, Ryan CA (1995) Salicylic acid inhibits synthesis of proteinase inhibitors in tomato leaves induced by systemin and jasmonic acid. Plant Physiol 108:17411746. https://doi.org/10.1104/pp.108.4.1741

Dugé de Bernonville T, Guyot S, Paulin J-P, Gaucher M, Loufrani L, Henrion D, Derbré S, Guilet D, Richomme P, Dat JF, Brisset M-N (2010) Dihydrochalcones: Implication in resistance to oxidative stress and bioactivities against advanced glycation end-products and vasoconstriction. Phytochemistry 71:443-452. https://doi. org/10.1016/j.phytochem.2009.11.004

Estonian Weather Service (2018) Meteorological Yearbook of Estonia 2017. Estonian Environment Agency, Tallinn

Forrester DI (2019) Linking forest growth with stand structure: Tree size inequality, tree growth or resource partitioning and the asymmetry of competition. For Ecol Manag 447:139-157. https://doi. org/10.1016/j.foreco.2019.05.053

Glauser G, Grata E, Dubugnon L, Rudaz S, Farmer EE, Wolfender J-L (2008) Spatial and temporal dynamics of jasmonate synthesis and accumulation in Arabidopsis in response to wounding. J Biol Chem 283:16400-16407. https://doi.org/10.1074/jbc.M801760200

Groenbaek M, Tybirk E, Neugart S, Sundekilde UK, Schreiner M, Kristensen HL (2019) Flavonoid glycosides and hydroxycinnamic acid derivatives in baby leaf rapeseed from white and yellow flowering cultivars with repeated harvest in a 2-years field study. Front Plant Sci. 10. https://doi.org/10.3389/fpls.2019.00355

Hamanishi ET, Barchet GL, Dauwe R, Mansfield SD, Campbell MM (2015) Poplar trees reconfigure the transcriptome and metabolome in response to drought in a genotype- and time-of-day-dependent manner. BMC Genomics 16:329. https://doi.org/10.1186/s12864-015-1535-Z

Hemming JDC, Lindroth RL (1995) Intraspecific variation in aspen phytochemistry: effects on performance of gypsy moths and forest tent caterpillars. Oecologia 103:79-88

Hepner H, Lutter R, Tullus A, Kanal A, Tullus T, Tullus H (2020) Effect of early thinning treatments on above-ground growth, biomass production, leaf area index and leaf growth efficiency in a hybrid aspen coppice stand. BioEnergy Res 13:197-209. https://doi.org/10.1007/s12155-020-10111-0

Herms DA, Mattson WJ (1992) The dilemma of plants: to grow or defend. Q Rev Biol 67:283-335

Huang H, Liu B, Liu L, Song S (2017) Jasmonate action in plant growth and development. J Exp Bot 68:1349-1359. https://doi. org/10.1093/jxb/erw495

Häikiö E, Freiwald V, Julkunen-Tiitto R, Beuker E, Holopainen T, Oksanen E (2008) Differences in leaf characteristics between ozone-sensitive and ozone-tolerant hybrid aspen (Populus tremula $\times$ Populus tremuloides) clones. Tree Physiol 29:53-66. https://doi.org/10.1093/treephys/tpn005

Hytönen J (2018) Biomass, nutrient content and energy yield of shortrotation hybrid aspen $(P$. tremula $\times$ P. tremuloides $)$ coppice. For Ecol Manag 413:21-31. https://doi.org/10.1016/j.foreco.2018.01.056

Ibdah M, Martens S, Gang DR (2018) Biosynthetic pathway and metabolic engineering of plant dihydrochalcones. J Agric Food Chem 66:2273-2280. https://doi.org/10.1021/acs.jafc.7b04445

IUSS Working Group WRB (2015) World Reference Base for Soil Resources 2014, update 2015 International soil classification system for naming soils and creating legends for soil maps. World Soil Resources Reports No. 106. FAO, Rome

Jacobo-Velázquez DA, González-Agüero M, Cisneros-Zevallos L (2015) Cross-talk between signaling pathways: the link between plant secondary metabolite production and wounding stress response. Sci Rep 5:8608. https://doi.org/10.1038/srep08608

Jervis J, Hildreth SB, Sheng X, Beers EP, Brunner AM, Helm RF (2015) A metabolomic assessment of NAC154 transcription factor overexpression in field grown poplar stem wood. Phytochemistry 115:112-120. https://doi.org/10.1016/j.phytochem.2015.02.013

Julkunen-Tiitto R, Nenadis N, Neugart S, Robson M, Agati G, Vepsäläinen J, Zipoli G, Nybakken L, Winkler B, Jansen MAK (2015) Assessing the response of plant flavonoids to UV radiation: an overview of appropriate techniques. Phytochem Rev 14:273-297. https://doi.org/10.1007/s11101-014-9362-4

Khan MIR, Khan NA (2013) Salicylic acid and jasmonates: approaches in abiotic stress tolerance. J Plant Biochem Physiol 1:4. https://doi.org/10.4172/2329-9029.1000e113

Kotilainen T, Tegelberg R, Julkunen-Tiitto R, Lindfors A, Aphalo PJ (2008) Metabolite specific effects of solar UV-A and UV-B on alder and birch leaf phenolics. Glob Change Biol 14:1294-1304. https://doi.org/10.1111/j.1365-2486.2008.01569.x

Lavola A (1998) Accumulation of flavonoids and related compounds in birch induced by UV-B irradiance. Tree Physiol 18:53-58

León J, Rojo E, Sánchez-Serrano JJ (2001) Wound signalling in plants. J Exp Bot 52:1-9. https://doi.org/10.1093/jexbot/52.354.1

Li X, Chen B, Xie H, He Y, Zhong D, Chen D (2018) Antioxidant structure-activity relationship analysis of five dihydrochalcones. Molecules 23:1162. https://doi.org/10.3390/molecules23051162

Long JN, Dean TJ, Roberts SD (2004) Linkages between silviculture and ecology: examination of several important conceptual models. For Ecol Manag 200:249-261. https://doi.org/10.1016/j. foreco.2004.07.005

Lutter R, Tullus A, Kanal A, Tullus T, Tullus H (2017) Above-ground growth and temporal plant-soil relations in midterm hybrid aspen ( Populus tremula L. $\times$ P. tremuloides Michx.) plantations on former arable lands in hemiboreal Estonia. Scand J For Res 32:688699. https://doi.org/10.1080/02827581.2017.1278784

Matyssek R, Agerer R, Ernst D, Munch J-C, Oßwald W, Pretzsch H, Priesack E, Schnyder H, Treutter D (2005) The plant's capacity in regulating resource demand. Plant Biol 7:560-580. https://doi. org/10.1055/s-2005-872981

Mc Carthy R, Rytter L (2015) Productivity and thinning effects in hybrid aspen root sucker stands. For Ecol Manag 354:215-223. https://doi.org/10.1016/j.foreco.2015.06.015 
Morales LO, Tegelberg R, Brosche M, Keinanen M, Lindfors A, Aphalo PJ (2010) Effects of solar UV-A and UV-B radiation on gene expression and phenolic accumulation in Betula pendula leaves. Tree Physiol 30:923-934. https://doi.org/10.1093/treephys/tpq051

Nakamura Y, Watanabe S, Miyake N, Kohno H, Osawa T (2003) Dihydrochalcones: evaluation as novel radical scavenging antioxidants. $\mathbf{J}$ Agric Food Chem 51:3309-3312. https://doi.org/10.1021/jf0341060

Neilson EH, Goodger JQD, Woodrow IE, Møller BL (2013) Plant chemical defense: at what cost? Trends Plant Sci 18:250-258. https://doi.org/10.1016/j.tplants.2013.01.001

Nissinen K, Virjamo V, Randriamanana T, Sobuj N, Sivadasan U, Mehtätalo L, Beuker E, Julkunen-Tiitto R, Nybakken L (2017) Responses of growth and leaf phenolics in European aspen (Populus tremula) to climate change during juvenile phase change. Can J For Res 47:1350-1363. https://doi.org/10.1139/cjfr-2017-0188

Pearl IA, Darling SF (1962) Studies on the barks of the family Salicaceae V. Grandidentatin, a new glucoside from the bark of Populus grandidentata. J Org Chem 27:1806-1809. https://doi. org/10.1021/jo01052a078

Pearl IA, Darling SF (1970) Studies on the barks of the family Salicaceae XX. Purpurein, a new glucoside from the bark of Salix purpurea. Phytochemistry 9:853-856. https://doi.org/10.1016/ S0031-9422(00)85192-4

Per TS, Khan MIR, Anjum NA, Masood A, Hussain SJ, Khan NA (2018) Jasmonates in plants under abiotic stresses: crosstalk with other phytohormones matters. Environ Exp Bot 145:104-120. https://doi.org/10.1016/j.envexpbot.2017.11.004

Pommerening A, Sánchez Meador AJ (2018) Tamm review: tree interactions between myth and reality. For Ecol Manag 424:164-176. https://doi.org/10.1016/j.foreco.2018.04.051

Popović BM, Štajner D, Ždero-Pavlović R, Tumbas-Šaponjac V, Čanadanović-Brunet J, Orlović S (2016) Water stress induces changes in polyphenol profile and antioxidant capacity in poplar plants (Populus spp.). Plant Physiol Biochem 105:242-250. https://doi.org/10.1016/j.plaphy.2016.04.036

Core Team R (2018) R: A Language and Environment for Statistical Computing. R Foundation for Statistical Computing, Vienna

Rhodes AC, Barney T, St. Clair SB, (2016) Stand composition, tree proximity and size have minimal effects on leaf function of coexisting aspen and subalpine fir. PLoS ONE 11:e0154395. https://doi.org/10.1371/journal.pone.0154395

Rusalepp L, Lutter R, Hepner H, Kaasik A, Tullus A (2020) Secondary metabolites in leaves of hybrid aspen (Populus tremula $\mathrm{L}$. $\times$ P. tremuloides Michx.). Zenodo. https://doi.org/10.5281/zenodo.4095450. Accessed 16 Oct 2020

Ruuhola T, Julkunen-Tiitto R (2003) Trade-off between synthesis of salicylates and growth of micropropagated Salix pentandra. J Chem Ecol 29:1565-1588. https://doi.org/10.1023/A:1024266612585
Ruuhola TM, Sipura M, Nousiainen O, Tahvanainen J (2001) Systemic induction of salicylates in Salix myrsinifolia (Salisb.). Ann Bot 88:483-497. https://doi.org/10.1006/anbo.2001.1491

Rytter L (2006) A management regime for hybrid aspen stands combining conventional forestry techniques with early biomass harvests to exploit their rapid early growth. For Ecol Manag 236:422-426. https://doi.org/10.1016/j.foreco.2006.09.055

Rytter L (2013) Growth dynamics of hardwood stands during the precommercial thinning phase - recovery of retained stems after competition release. For Ecol Manag 302:264-272. https://doi. org/10.1016/j.foreco.2013.03.034

Si C-L, Xu J, Kim J-K, Bae Y-S, Liu P-T, Liu Z (2011) Antioxidant properties and structural analysis of phenolic glucosides from bark of Populus ussuriensis Kom. Wood Sci Technol 45:5-13. https://doi.org/10.1007/s00226-009-0286-x

Smith JL, De Moraes CM, Mescher MC (2009) Jasmonate- and salicylate-mediated plant defense responses to insect herbivores, pathogens and parasitic plants. Pest Manag Sci 65:497-503. https://doi. org/10.1002/ps.1714

Snyder DT, Schilling MC, Hochwender CG, Kaufman AD (2015) Profiling phenolic glycosides in Populus deltoides and Populus grandidentata by leaf spray ionization tandem mass spectrometry. Anal Methods 7:870-876. https://doi.org/10.1039/C4AY02639J

Stamp N (2003) Out of the quagmire of plant defense hypotheses. Q Rev Biol 78:23-55

Svyatyna K, Riemann M (2012) Light-dependent regulation of the jasmonate pathway. Protoplasma 249:137-145. https://doi. org/10.1007/s00709-012-0409-3

Tullus A, Rytter L, Tullus T, Weih M, Tullus H (2012) Short-rotation forestry with hybrid aspen (Populus tremula L. $\times$ P. tremuloides Michx.) in Northern Europe. Scand J For Res 27:10-29. https://doi.org/10.1080/02827581.2011.628949

Tullus A, Tullus H, Vares A, Kanal A (2007) Early growth of hybrid aspen (Populus wettsteinii Hämet-Ahti) plantations on former agricultural lands in Estonia. For Ecol Manag 245:118-129. https://doi.org/10.1016/j.foreco.2007.04.006

Valle JCD, Buide ML, Whittall JB, Valladares F, Narbona E (2020) UV radiation increases phenolic compound protection but decreases reproduction in Silene littorea. PLoS ONE 15:e0231611. https://doi.org/10.1371/journal.pone.0231611

Warren JM, Bassman JH, Fellman JK, Mattinson DS, Eigenbrode S (2003) Ultraviolet-B radiation alters phenolic salicylate and flavonoid composition of Populus trichocarpa leaves. Tree Physiol 23:527-535. https://doi.org/10.1093/treephys/23.8.527

Wasternack C, Strnad M (2018) Jasmonates: news on occurrence, biosynthesis, metabolism and action of an ancient group of signaling compounds. Int J Mol Sci 19. https://doi.org/10.3390/ijms19092539 


\section{Affiliations}

\section{Linda Rusalepp ${ }^{1,2}$ (D) $\cdot$ Reimo Lutter $^{3,4}$ (D) Heiki Hepner ${ }^{3} \cdot$ Ants Kaasik $^{1}$ (D) Arvo Tullus $^{1}$ (D)}

Reimo Lutter

reimo.lutter@emu.ee

Heiki Hepner

heiki.hepner@riigikogu.ee

Ants Kaasik

ants.kaasik@ut.ee

Arvo Tullus

arvo.tullus@ut.ee

1 Institute of Ecology and Earth Sciences, University of Tartu, Lai 40, 51003 Tartu, Estonia
2 Institute of Veterinary Medicine and Animal Sciences, Estonian University of Life Sciences, Kreutzwaldi 62, 51006 Tartu, Estonia

3 Institute of Forestry and Rural Engineering, Estonian University of Life Sciences, Kreutzwaldi 5, 51006 Tartu, Estonia

4 Department of Forest Ecology and Management, Swedish University of Agricultural Sciences, Skogsmarksgränd 17, 90183 Umeå, Sweden 